\title{
Pengaruh Media Pembelajaran Dan Kemandirian Belajar Terhadap Hasil Belajar Sejarah Siswa SMA
}

Setiawan Arief Wijayanto

SMA Negeri 2 Cikarang Selatan Kabupaten Bekasi

\begin{abstract}
Abstrak
Penelitian ini bertujuan untuk mengungkapkan pengaruh media pembelajaran dan kemandirian belajar terhadap hasil belajar siswa sejarah. Penelitian ini dilakukan di SMA Negeri 1 Cikarang Selatan Bekasi tahun pelajaran 2012/2013. Metode penelitian yang digunakan dalam penelitian ini adalah metode eksperimen dengan desain faktorial $2 \times 2$. Populasi penelitian adalah siswa kelas sebelas dengan 36 subjek sampel uji coba kedua, diambil dari dua kelas dengan media pembelajaran yang berbeda, 18 orang dengan media pembelajaran flash player. dan 18 orang dengan media konvensional. Hasil penelitian menunjukkan bahwa (1) Dari pembelajaran sejarah siswa yang menggunakan media pembelajaran flash player lebih tinggi daripada yang menggunakan pembelajaran media konvensional, (2) Ada interaksi antara media pembelajaran dan kemandirian belajar terhadap hasil pembelajaran sejarah, (3) Siswa dengan kemandirian belajar tinggi mencapai hasil belajar sejarah jika menggunakan media pembelajaran flash player dari pada menggunakan media konvensional, (4) Siswa dengan kemandirian belajar rendah dapat mencapai hasil pembelajaran sejarah jika menggunakan media konvensional dari pada yang menggunakan media pembelajaran flash player.
\end{abstract}

\section{Kata Kunci: Hasil Belajar Sejarah, Media, Kemandirian}

\section{Pendahuluan}

Strategi pembelajaran sejarah yang digunakan, baik metode maupun media yang selama ini dikembangkan atau dipraktekkan di sekolah sebagian besar masih bersifat konvensional. Guru lebih banyak menggunakan metode ceramah sehingga menimbulkan kesan bahwa sejarah hanya merupakan hafalan peristiwa di masa lampau yang mencakup nama-nama raja, kerajaan dan angka tahun.

Ada anggapan pula dari siswa bahwa sejarah dapat dipelajari sendiri, tanpa harus ada bimbingan dari guru. Dalam hal ini yang penting ada buku atau sumber belajar lainnya. Dampaknya siswa kurang memperhatikan penjelasan guru ketika pelajaran berlangsung, dengan anggapan di rumah pun materi tersebut dapat dicari dan dipelajari sendiri. Selama ini mata pelajaran sejarah dianggap sebagai pelajaran yang dengan cerita dongeng dan lebih banyak hafalannya (Susanto Zuhdi: 2010). Hal ini disebabkan guru dalam penyajian materi sering hanya terfokus pada siapa, dimana dan kapan peristiwa itu terjadi. Guru sejarah minim memperhatikan keterkaitan antara peristiwa dengan peristiwa lain.

Oleh karena itu, pembaharuan dalam pembelajaran sejarah sangat diperlukan. Terutama dalam hal metode yang digunakan atau bagaimana menggunakan media belajar yang menarik bagi siswa. Berdasarkan hal tersebut, maka diperlukan alat bantu pembelajaran untuk mempermudah proses penyampaian 
informasi. Alat bantu tersebut secara umum disebut sebagai multimedia. Menurut Haffost (dalam Munir, 2008: 233) menyatakan multimedia adalah suatu sistem komputer yang berupa software dan hardware yang memberikan kemudahan untuk menggabungkan gambar, video, fotografi, grafik dan animasi dengan suara, teks dan data yang dikendalikan dengan program komputer. Media seperti ini diharapkan dapat membuat siswa termotivasi dalam mengikuti pembelajaran yang bisa menumbuhkembangkan daya pikir dan kreativitas siswa, serta memungkinkan terjadinya belajar mandiri.

Akan tetapi perlu diingat bahwa tercapainya hasil belajar sejarah, tidak sekedar tergantung dari cara mengajar dan media yang digunakan guru. Hal ini tergantung juga pada karakteristik siswa masing-masing. Salah satu karakteristik yang di duga mempunyai pengaruh cukup besar adalah kemandirian belajar siswa. Menurut Sumahamijaya (2003: 30) istilah kemandirian berasal dari kata dasar mandiri yang berarti dalam keadaan berdiri sendiri, tidak bergantung keada orang lain, dengan kekuatan sendiri.

Oleh sebab itu, kemandirian diartikan sebagai suatu keadaan dapat berdiri sendiri tanpa bergantung kepada orang lain. Kemampuan belajar mandiri menjadi lebih diperlukan siswa dalam menghadapi tugas mandiri, tugas dalam bentuk proyek, dan sebagainya. Ketika menghadapi tugas-tugas seperti itu, siswa sebenarnya dihadapkan pada berbagai sumber belajar yang melimpah yang mungkin relevan atau tidak relevan dengan kebutuhan dan tujuan yang bersangkutan. Dalam kondisi seperti ini, siswa harus memiliki inisiatif sendiri dan motivasi intrinsik, menganalisis kebutuhan, merumuskan tujuan, memilih dan menerapkan strategi pemecahan masalah, menseleksi sumber yang relevan, serta mengevaluasi diri.

Kemandirian belajar menjadi syarat untuk membentuk siswa yang berkualitas. Pada akhirnya pemanfaatan media memungkinkan tercapainya efektivitas pembelajaran mandiri pada siswa dan meningkatkan hasil belajar siswa dalam mata pelajaran sejarah. Dengan demikian, masalah yang muncul dalam penelitian ini 1). Apakah terdapat perbedaan hasil belajar sejarah antara siswa yang menggunakan media pembelajaran flash player dengan siswa menggunakan media konvensional, 2). Apakah terdapat pengaruh interaksi antara media pembelajaran dan kemandirian belajar terhadap hasil belajar sejarah siswa SMA, 3). Apakah terdapat perbedaan hasil belajar sejarah siswa yang menggunakan media pembelajaran flash player dan media pembelajaran konvensional bagi siswa yang memiliki kemandirian belajar tinggi, serta 4). Apakah terdapat perbedaan hasil belajar sejarah siswa yang menggunakan media 
pembelajaran flash player dan media pembelajaran konvensional bagi siswa yangmemiliki kemandirian belajar rendah. Tujuan penelitian ini untuk memberikan alternatif dalam mengelola pembelajaran kreatif, efektif dan menyenangkan terutama dalam pemilihan media pembelajaran yang mempertimbangkan tingkat kemandirian belajar siswa SMA.

\section{Tinjauan Pustaka}

\section{A. Media Pembelajaran}

Secara umum media pembelajaran dalam pendidikan disebut media, yaitu berbagai jenis komponen dalam lingkungan siswa yang dapat merangsangnya untuk berpikir. Menurut Briggs (dalam Sadiman, 2011: 6) media adalah segala alat fisik yang dapat menyajikan pesan serta merangsang siswa untuk belajar. Maka, media merupakan segala sesuatu yang dapat digunakan untuk menyalurkan pesan dari pengirim kepada penerima sehingga dapat merangsang pikiran, perasaan, minat dan perhatian sedemikian rupa sehingga proses belajar terjadi.

Smaldino (2005: 9) mengungkapkan kata media digunakan sebagai apapun yang dapat menyampaikan informasi dari sumber informasi menuju penerima informasi, misalnya video, televisi, diagram. Berdasarkan pendapat sebelumnya, media adalah sarana penunjang guru dalam menyampaikan pesan kepada siswa. Terjadinya pengalaman belajar yang bermakna antara guru dengan siswa tidak terlepas dari peran media, terutama dari kedudukan dan fungsinya. Peranan media pembelajaran menurut Rusman (2009: 154) dapat dijelaskan, 1). Alat untuk memperjelas bahan pembelajaran saat guru menyampaikan pelajaran. Dalam media ini digunakan guru sebagai variasi penjelasan verbal mengenai bahan pembelajaran,

2). Alat untuk mengangkat atau menimbulkan persoalan untuk dikaji lebih lanjut oleh siswa dalam proses belajarnya. Paling tidak guru dapat menempatkan media sebagai sumber pertanyaan atau stimulasi belajar siswa, dan 3). Sumber belajar bagi siswa, artinya media tersebut berisikan bahan yang harus dipelajari para siswa baik individual maupun kelompok. Dengan demikian akan banyak membantu tugas guru dalam kegiatan mengajarnya.

Penggunaan media pembelajaran dalam proses pembelajaran dapat memperjelas penyajian pesan dan informasi, dapat meningkatkan dan mengarahkan perhatian anak sehingga dapat menimbulkan motivasi belajar, sikap kemandirian belajar, serta dapat mengatasi keterbatasan indera, ruang dan waktu.

\section{B. Media Pembelajaran Konvensional}

Media belajar konvensional disebut juga sebagai media mengajar. Pengguna media pembelajaran lebih banyak oleh kalangan guru. Media pembelajaran konvensional lebih banyak dipergunakan untuk memperjelas materi yang ingin 
disampaikan guru kepada para siswa. Sifat media yang demikian tidak akan membangun proses diskusi dan dialog. Walaupun media digunakan oleh siswa, namun penggunaan media di sini hanya untuk membantu transfer pengetahuan dari guru kepada murid. Media pembelajaran konvensional menetapkan isi pesan dari media yang dipergunakan, dalam rangka mencapai tujuan dari pemberi pesan.

Komunikasi pembelajaran yang dikembangkan adalah satu arah dengan umpan balik hanya sebagai cara memeriksa apakah pesan telah diterima dengan baik. Bisa saja model komunikasi konvensional menggunakan media yang penggunaannya secara partisipatif. Namun hakekatnya tetap sama yaitu menyampaikan pesan atau informasi yang ditetapkan secara sepihak. Ini berarti media yang dikembangkan hanya merupakan alat untuk mengefektifkan penyampaian materi. Media konvensional umumnya mudah untuk digunakan, tidak memerlukan pelatihan khusus bagi penggunanya, dan mudah didapat.

Media konvensional yang digunakan dalam penelitian ini adalah media power point. Power point adalah salah satu jenis program produk dari Microsoft. Microsoft power point merupakan program aplikasi yang dirancang khusus untuk menampilkan program multimedia. Sebagaimana yang dikemukakan Susilana dan Riyana (2008: 102) bahwa program power point adalah salah satu software yang dirancang khusus untuk menampilkan program multimedia dengan menarik, mudah dalam pembuatan, mudah dalam penggunaan dan relatif murah, karena tidak membutuhkan bahan baku selain alat untuk penyimpanan data.

Microsoft power point memiliki kemampuan untuk menggabungkan berbagai unsur media, seperti pengolahan tekas, warna, gambar, dan grafik, serta animasi. Berdasarkan penjelasan di atas maka dapat disimpulkan bahwa Microsoft power point merupakan perangkat lunak (software) yang mampu menampilkan program multimedia dengan menarik, mudah dalam pembuatan dan penggunaannya relatif murah.

\section{Media Pembelajaran Flash Player}

Flash merupakan salah satu teknologi komputasi multimedia. Multimedia diartikan sebagai kombinasi dari teks, grafik, animasi suara dan video yang digabung menjadi satu kesatuan kerja. Media tersebut menghasilkan informasi yang memiliki nilai komunikasi interaktif yang tinggi bukan hanya dilihat sebagai hasil cetakan. Melainkan dapat didengar dan membentuk simulasi dan animasi yang memiliki seni grafis yang tinggi dalam penyampaian.

Macromedia Flash merupakan sebuah program yang didesain khusus oleh Macromedia. Waktu itu sebagai pengembangnya yang saat ini sudah dibeli oleh Adobe Incorporated sehingga berubah nama menjadi Adobe Flash. Menurut Andi 
(2004: 45) flash di desain dengan kemampuan untuk membuat animasi dua dimensi yang handal dan ringan sehingga flash banyak digunakan untuk membangun dan memberikan efek animasi pada website, CD Interaktif dan yang lain. Media flash player berkaitan dengan software untuk membuat animasi yang biasanya digunakan untuk berbagai keperluan di internet.

Misalnya, untuk membuat situs, banner iklan, logo yang beranimasi, serta animasi pelengkap lainnya. Terkait dengan karakteristik multimedia, dapat diketahui dengan kegunaan flash player ini yaitu bila pengguna mendapatkan keleluasaan dalam mengontrol multimedia tersebut, maka flash player tergolong multimedia interaktif.

Menurut Levie (dalam Arsyad, 2012:

17) terdapat empat kelebihan media pembelajaran visual, yaitu 1). Fungsi atensi yaitu menarik dan mengarahkan perhatian siswa untuk berkonsentrasi kepada isi pelajaran yang berkaitan dengan makna visual yang ditampilkan atau menyertai teks materi pelajaran, 2). Fungsi afektif yaitu media visual dapat dilihat dari tingkat kenikmatan siswa ketika belajar teks yang bergambar, 3). Fungsi kognitif yaitu media visual dapat memperlancar pencapaian tujuan untuk memahami dan mengingat informasi atau pesan yang terkandung dalam gambar, dan 4). Fungsi konpensatoris yaitu akan memudahkan siswa yang lemah mengorganisasi hasil bacaannya dalam teks dan mengingatnya kembali.

\section{Kemandirian Belajar}

Salah satu aspek kepribadian dari individu adalah kemandirian. Setiap proses pembelajaran siswa diarahkan agar selalu mandiri, dan untuk menjadi mandiri siswa harus belajar. Berikut beberapa pengertian tentang kemandirian maupun kemandirian belajar dari beberapa ahli. Constance Kamii (2000: 56) menyatakan bahwa mandiri atau kemandirian berarti diperintah oleh diri sendiri, dimana setiap pribadi berhak membuat keputusan bagi diri sendiri tanpa bergantung orang lain. Jadi kemandirian adalah kecenderungan menggunakan kemampuan diri sendiri untuk menyelesaikan masalah secara bebas dan penuh inisiatif.

Mengacu pendapat Uno (2012: 77) kemandirian mengandung arti kemampuan untuk mengarahkan dan mengendalikan diri, berdiri dengan kaki sendiri. Kaitannya dengan kemandirian dalam pembelajaran. Menurut Miarso (2004:267) bahwa belajar mandiri prinsipnya sangat erat hubungannya dengan belajar menyelidik, yaitu berupa pengarahan dan pengontrolan diri dalam memperoleh dan menggunakan pengetahuan. Pendapat ini mengandung arti bahwa keberhasilan siswa dapat diukur dari kesanggupan bertindak dan berpikir sendiri, dan tidak tergantung kepada orang lain. Paling tidak ada dua kemungkinan untuk melaksanakan prinsip ini, yaitu 1). digunakan program belajar yang mengandung petunjuk untuk belajar sendiri 
oleh siswa dengan sedikit bantuan dari guru, dan 2) melibatkan siswa dalam merencanakan dan melaksanakan kegiatan. Berdasarkan uraian tersebut, dapat dimaknai bahwa kemandirian belajar diartikan sebagai proses belajar pada diri seseorang, yang mana untuk mencapai tujuan belajar dituntut aktif, tidak tergantung orang lain termasuk guru sendiri. Guru hanya berperan sebagai pembimbing atau fasilitator, misal ketika siswa mengalami kesulitan dalam belajar.

\section{E. Hasil Belajar Sejarah}

Skinner (dalam Thobroni \& Arif Mustofa, 2011: 77-80) menyatakan bahwa belajar merupakan suatu perilaku. Pengulangan dan pelatihan diperlukan supaya perilaku yang diinginkan dapat menjadi kebiasaan. Hamalik (2012: 27) menerangkan bahwa belajar adalah modifikasi atau memperteguh kelakuan melalui pengalaman. Dalam pengertian ini, belajar merupakan suatu proses dan suatu kegiatan yang menghasilkan berubahnya kelakuan dan proses mengalami bukan hanya dari proses mengingat.

Berdasarkan pendapat tersebut, dimaknai bahwa belajar adalah proses perubahan tingkah laku sehingga menghasilkan perubahan dalam pengetahuan, pemahaman, nilai dan sikap yang dilakukan oleh seseorang atau siswa melalui latihan dan pengalaman dalam interaksinya dengan lingkungan. Gagne dalam teorinya, conditions of learning, mengemukakan bahwa hasil belajar tercermin dalam kecakapan manusiawi, yang mencakup 1). informasi verbal, 2). kemampuan intelektual yang meliputi diskriminasi, konsep konkrit, konsep abstrak, aturan-aturan yang lebih tinggi, 3). strategi kognitif, 4). sikap, dan 5). keterampilan. Menurut Djamarah (2006: 32) mengemukakan hasil belajar merupakan prestasi dan kesan yang diperoleh dan mengakibatkan perubahan diri individu sebagai aktivitas hasil belajar.

Dalam proses pembelajaran, hasil belajar memiliki fungsi seperti yang diungkapkan W.S. Winkel (2009: 104), yaitu 1). Hasil belajar sebagai indikator kualitas dan kuantitas pengetahuan yang telah dikuasai anak didik, 2). Hasil belajar sebagai lambang pemusatan hasrat keinginan, 3). Hasil belajar sebagai bahan informasi dalam inovasi pendidikan, 4). Hasil belajar sebagai indikator intern dan ekstern dari situasi institusi pendidikan, dan 5). Hasil belajar dapat dijadikan indikator terhadap daya serap kecerdasan anak didik. Berdasarkan pendapat tersebut, hasil belajar adalah suatu perubahan siswa dari segi pengetahuan, sikap dan ketrampilan setelah mengikuti proses pembelajaran.

\section{Metode Penelitian}

Metode yang digunakan dalam penelitian ini adalah metode eksperimen. Penggunaan metode ini untuk menguji pengaruh penerapan media pembelajaran 
dan kemandirian belajar terhadap hasil belajar sejarah pada siswa SMA. Penelitian ini menggunakan desain treatment by level 2 x 2 seperti tertera pada matrik dibawah ini:

Tabel 1. Matrik Desain Penelitian

\begin{tabular}{|l|c|c|c|}
\hline \multirow{2}{*}{$\begin{array}{c}\text { Kemandirian } \\
\text { Belajar } \\
(\mathrm{B})\end{array}$} & \multicolumn{2}{|c|}{ Media Pembelajaran $(\mathrm{A})$} & \multirow{2}{*}{ Jumlah } \\
\cline { 2 - 3 } & $\begin{array}{c}\text { Flash } \\
\text { Player }\left(\mathrm{A}_{1}\right)\end{array}$ & $\begin{array}{c}\text { Konvensional } \\
\left(\mathrm{A}_{2}\right)\end{array}$ & \\
\hline Tinggi $\left(\mathrm{B}_{1}\right)$ & $A_{1} \mathrm{~B}_{1}=9$ & $A_{2} \mathrm{~B}_{1}=9$ & 36 \\
\hline Rendah $\left(\mathrm{B}_{2}\right)$ & $A_{1} \mathrm{~B}_{2}=9$ & $A_{2} \mathrm{~B}_{2}=9$ & 36 \\
\hline Jumlah & 18 & 18 & 36 \\
\hline
\end{tabular}

Populasi target penelitian ini adalah semua siswa SMA Negeri 1 Cikarang Selatan Kabupaten Bekasi. Sampel populasi adalah siswa kelas XI Program IPA yang mengikuti mata pelajaran sejarah Tahun Pelajaran 2012/2013. Pengambilan sampel dilakukan dengan teknik multi-stage random sampling. Pertama, SMA Negeri 1 Cikarang Selatan sebagai tempat penelitian. Kedua, menetapkan siswa yaitu kelas XI program IPA sebagai kelas penelitian.

Ketiga, memilih dua kelas dari keempat kelas yang ada yaitu XI IPA 1, XI IPA 2, XI IPA 3 dan XI IPA 4 dengan pengundian untuk dijadikan kelas dengan perlakuan media pembelajaran flash player dan media pembelajaran konvensional. Keempat, terpilih kelas XI IPA 1 untuk media pembelajaran flash player dan kelas XI IPA 2 untuk media pembelajaran konvensional. Kelima, masing-masing kelompok dibagi menjadi dua kelompok, yaitu beranggotakan siswa dengan kemandirian belajar tinggi dan kemandirian belajar rendah.

\section{Tabel 2. Rancangan Perlakuan}

\begin{tabular}{|c|c|c|}
\hline $\begin{array}{c}\text { Kegiatan } \\
\text { Pembela- } \\
\text { jaran }\end{array}$ & $\begin{array}{c}\text { Media } \\
\text { Pembelajaran } \\
\text { Flash Player }\end{array}$ & $\begin{array}{c}\text { Media } \\
\text { Pembelajaran } \\
\text { Konvensional }\end{array}$ \\
\hline $\begin{array}{l}\text { Kegiatan } \\
\text { Pendahu- } \\
\text { luan } \\
(5-10 \\
\text { menit) }\end{array}$ & $\begin{array}{l}\text { 1. Guru dan siswa } \\
\text { mengawali } \\
\text { kegiatan } \\
\text { pembelajaran } \\
\text { dengan berdoa } \\
\text { bersama. } \\
\text { 2. } \\
\text { Guru } \\
\text { menyampaikan } \\
\text { tujuan } \\
\text { pembelajaran } \\
\text { yang akan dicapai } \\
\text { dan tugas-tugas } \\
\text { yang harus } \\
\text { dikerjakan } \\
\text { Guru } \\
\text { mempersiapkan } \\
\text { media } \\
\text { pembelajaran } \\
\text { flash player yang } \\
\text { akan digunakan } \\
\text { untuk } \\
\text { pembelajaran }\end{array}$ & $\begin{array}{l}\text { 1. Guru dan siswa } \\
\text { mengawali } \\
\text { kegiatan } \\
\text { pembelajaran } \\
\text { dengan berdoa } \\
\text { bersama. } \\
\text { 2. Guru } \\
\text { menyampaikan } \\
\text { tujuan akan } \\
\text { pembelajaran } \\
\text { yang dan } \\
\text { dicapai yang } \\
\text { tugas-tugas yan } \\
\text { harus dikerjakan } \\
\text { Guru akan } \\
\text { mempersiapkan } \\
\text { media a } \\
\text { pembelajaran } \\
\text { konvensional } \\
\text { yang a antuk } \\
\text { digunakan untul } \\
\text { pembelajaran }\end{array}$ \\
\hline $\begin{array}{l}\text { Kegiatan } \\
\text { Inti } \\
\text { (30-35 } \\
\text { menit) }\end{array}$ & 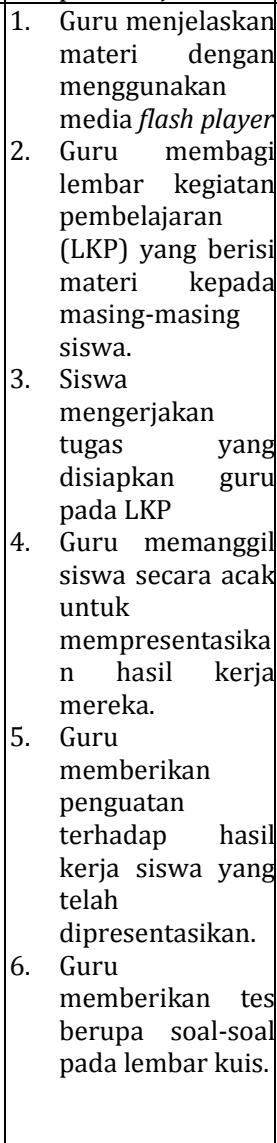 & $\begin{array}{l}\text { 1. Guru } \\
\text { menjelaskan } \\
\text { materi dengan } \\
\text { menggunakan } \\
\text { media } \\
\text { konvensional } \\
\text { 2. Guru membagi } \\
\text { lembar kegiatan } \\
\text { pembelajaran } \\
\text { (LKP) yang berisi } \\
\text { materi kepada } \\
\text { masing-masing } \\
\text { siswa. } \\
\text { 3. Siswa } \\
\text { mengerjakan } \\
\text { tugas yang } \\
\text { disiapkan guru } \\
\text { pada LKP } \\
\text { Guru memanggil } \\
\text { siswa secara acak } \\
\text { untuk } \\
\text { mempresentasik } \\
\text { an hasil kerja } \\
\text { mereka. } \\
\text { Guru } \\
\text { memberikan } \\
\text { penguatan } \\
\text { terhadap hasil } \\
\text { kerja siswa yang } \\
\text { telah } \\
\text { dipresentasikan. } \\
\text { Guru tes } \\
\text { memberikan } \\
\text { berupa soal-soal } \\
\text { pada lembar kuis. }\end{array}$ \\
\hline $\begin{array}{l}\text { Kegiatan } \\
\text { penutup } \\
(5-10 \\
\text { menit) }\end{array}$ & $\begin{aligned} & \text { 1. } \text { Guru dan siswa } \\
& \text { bersama-sama } \\
& \text { menyimpulkan } \\
& \text { hasil } \\
& \text { pembelajaran. } \\
& \text { 2. } \text { Guru } \\
& \text { memberikan } \\
& \text { penghargaan } \\
& \text { pada siswa. }\end{aligned}$ & $\begin{array}{l}\text { 1. Guru dan sisw } \\
\text { bersama-sama } \\
\text { menyimpulkan } \\
\text { hasil } \\
\text { pembelajaran. } \\
\text { 2. } \\
\text { Guru } \\
\text { memberikan } \\
\text { penghargaan } \\
\text { pada siswa. }\end{array}$ \\
\hline
\end{tabular}


Untuk pengujian hipotesis dalam penelitian ini digunakan teknik analisis varians dua jalur (ANAVA $2 \times 2$ 2). Sebab jumlah $\mathrm{n} / \mathrm{sel}$ sama maka perhitungan uji lanjut memakai uji Tuckey, dan dilakukan manakala ditemukan pengaruh interaksi antara media pembelajaran dan kemandirian belajar terhadap hasil belajar sejarah siswa SMA. Sebelum uji ANAVA terlebih dahulu dilakukan uji persyaratan analisis yaitu meliputi uji normalitas data dan uji homogenitas variansi. Untuk melihat normalitas data akan digunakan uji Lilifors, sedangkan untuk melihat homogenitas variansi dengan uji Bartlet.

\section{Hasil Dan Pembahasan}

Berdasarkan jumlah variabel penelitian, maka deskripsi data dapat diringkaskan pada Tabel 3 berikut ini:

Tabel 3. Rangkuman Skor Hasil Belajar Sejarah

\begin{tabular}{|c|c|c|c|c|c|c|}
\hline \multirow{2}{*}{$\begin{array}{l}\text { Media Pembelaiaran } \\
\text { Kemandirian Belajar }\end{array}$} & \multicolumn{2}{|c|}{$\begin{array}{l}\text { Media Flash Player } \\
\qquad\left(A_{1}\right)\end{array}$} & \multicolumn{2}{|c|}{$\begin{array}{c}\text { Media Konvensional } \\
\qquad\left(A_{2}\right)\end{array}$} & \multicolumn{2}{|c|}{ Total } \\
\hline & $n_{1}=$ & 9 & $n_{2}=$ & 9 & $n_{61}=$ & 18 \\
\hline \multirow{4}{*}{ Tinggi $\left(B_{1}\right)$} & $X_{1}=$ & 220 & $X_{2}=$ & 124 & $\mathrm{X}_{\mathrm{b} 1}=$ & 344 \\
\hline & $X_{1}^{2}=$ & 5416 & $X_{2}{ }^{2}=$ & 1756 & $X_{b 1}{ }^{2}=$ & 7172 \\
\hline & $x_{1}=$ & 24.44 & $x_{2}=$ & 13.78 & $\mathrm{x}_{61}=$ & 19.11 \\
\hline & $\left(X_{1}\right)^{2}=$ & 48400 & $\left.X_{1}\right)^{2}=$ & 15376 & $\left(X_{b 2}\right)^{2}=$ & 118336 \\
\hline \multirow{5}{*}{ Rendah $\left(B_{z}\right)$} & $n_{3}=$ & 9 & $n_{4}=$ & 9 & $n_{62}=$ & 18 \\
\hline & $X_{3}=$ & 123 & $X_{4}=$ & 170 & $X_{62}=$ & 293 \\
\hline & $X_{3^{2}}=$ & 1725 & $X_{1}{ }^{2}=$ & 3288 & $\mathrm{X}_{\mathrm{b} z^{2}}{ }^{2}$ & 5013 \\
\hline & $x_{3}=$ & 13.67 & $x_{4}=$ & 18.89 & $\mathrm{x}_{62}=$ & 16.28 \\
\hline & $\left(X_{3}\right)^{2}=$ & 15129 & $\left.X_{6}\right)^{2}=$ & 28900 & $\left(X_{b 2}\right)^{2}=$ & 85849 \\
\hline \multirow{5}{*}{ Total } & $n_{k 1}=$ & 18 & $n_{k 2}=$ & 18 & $n_{s}=$ & 36 \\
\hline & $X_{k 1}=$ & 343 & $X_{k 2}=$ & 294 & $x_{x}=$ & 637 \\
\hline & $\mathrm{X}_{\mathrm{k} 2}{ }^{2}=$ & 7141 & $3 k^{2}=$ & 5044 & $\mathrm{X}_{\mathrm{t}}^{2}=$ & 12185 \\
\hline & $\mathrm{x}_{k 1}=$ & 19.06 & $x_{k 2}=$ & 16.33 & $x_{\mathrm{s}}=$ & 17.694 \\
\hline & $\left(X_{k 1}\right)^{2}=$ & 117649 & $\begin{array}{c}\left.X_{k 2}\right)^{2} \\
=\end{array}$ & 86436 & $\left(x_{0}\right)^{2}=$ & 405769 \\
\hline
\end{tabular}

Keterangan :

$\mathrm{n}$ = banyaknya sampel

$\mathrm{x}=$ skor hasil belajar sejarah

Berdasarkan rancangan eksperimen yang telah disusun dalam penelitian ini, maka ada enam kelompok hasil belajar yang akan dideskripsikan secara terpisah. Keenam kelompok tersebut adalah 1). hasil belajar sejarah siswa yang belajar menggunakan media pembelajaran flash player, 2). hasil belajar sejarah siswa yang belajar menggunakan media pembelajaran konvensional, 3). hasil belajar sejarah siswa yang belajar menggunakan media pembelajaran flash player dengan kemandirian belajar tinggi, 4) hasil belajar sejarah siswa yang belajar menggunakan media pembelajaran flash player dengan kemandirian belajar rendah, 5) hasil belajar sejarah siswa yang belajar menggunakan media pembelajaran konvensional dengan kemandirian belajar tinggi, dan 6) hasil belajar sejarah siswa belajar menggunakan media pembelajaran konvensional dengan kemandirian belajar rendah.

Pengujian hipotesis dalam penelitian ini dilakukan menggunakan analisis varians dua jalur dengan interaksi (ANAVA 2 x 2) dan dilanjutkan dengan Uji Tuckey, jika terdapat interaksi di dalam pengujian. Analisis varians dua jalur digunakan untuk menguji pengaruh utama (main effect) dan interaksi (interaction effect) antara media pembelajaran dan kemandirian belajar terhadap hasil belajar sejarah siswa.

\section{A. Uji Hipotesis Pertama}

Terdapat perbedaan hasil belajar sejarah siswa yang belajar menggunakan media pembelajaran flash player dan siswa yang belajar menggunakan media 
konvensional. Secara statistik, hipotesis ini dirumuskan sebagai berikut:

$\mathrm{H}_{0}: \mu_{\mathrm{A} 1} \leq \mu_{\mathrm{A} 2}$

$\mathrm{H}_{1}: \mu_{\mathrm{A} 1}>\mu_{\mathrm{A} 2}$

Keterangan :

$\mu_{\mathrm{A} 1}=$ Rata-rata hasil belajar sejarah kelompok siswa belajar menggunakan media pembelajaran flash player.

$\mu_{\mathrm{A} 2}=$ Rata-rata hasil belajar sejarah kelompok siswa belajar menggunakan media pembelajaran konvensional.

Berdasarkan tabel ANAVA diatas, diperoleh $F_{\text {hitung }}=10,327$ lebih besar dari $F_{\text {tabel }}=4,20$ pada taraf signifikansi $\alpha=0,05$. Karena nilai $F_{\text {hitung }}>F_{\text {tabel, }}$ maka disimpulkan bahwa $\mathrm{H}_{0}$ ditolak dan $\mathrm{H}_{1}$ diterima kebenarannya. Hal ini membuktikan ada perbedaan hasil belajar sejarah siswa yang belajar menggunakan media pembelajaran flash player dan siswa yang belajar menggunakan media konvensional.

\section{B. Uji Hipotesis Kedua}

Terdapat Pengaruh Interaksi Antara Penggunaan Media Pembelajaran Dan Kemandirian Belajar Terhadap Hasil Belajar Sejarah Siswa SMA. Secara statistik, hipotesis ini dirumuskan:

$\mathrm{H}_{0}$ : INT. $\mathrm{A} \times \mathrm{B}=0$

$\mathrm{H}_{1}$ : INT. $\mathrm{A} \times \mathrm{B} \neq 0$

Keterangan :

$\mathrm{H}_{0} \quad$ = Tidak terdapat interaksi antara media pembelajaran dan kemandirian belajar siswa SMA

$$
\begin{aligned}
\mathrm{H}_{1}= & \text { Terdapat interaksi antara media } \\
& \text { pembelajaran dan kemandirian } \\
& \text { belajar siswa SMA } \\
& \text { Berdasarkan tabel ANAVA diatas, }
\end{aligned}
$$
diperoleh $\mathrm{F}_{\text {hitung }}=87,953$ lebih besar dari $F_{\text {tabel }}=7,50$ pada taraf signifikansi $\alpha=0,05$. Karena nilai $F_{\text {hitung }}>F_{\text {tabel, }}$ maka disimpulkan bahwa $\mathrm{H}_{0}$ ditolak dan $\mathrm{H}_{1}$ diterima kebenarannya. Hal ini membuktikan terdapat pengaruh interaksi antara media pembelajaran dan kemandirian belajar terhadap hasil belajar sejarah siswa SMA.

\section{Uji Hipotesis Ketiga}

Hasil belajar sejarah siswa yang belajar menggunakan media pembelajaran flash player lebih tinggi dibandingkan dengan media pembelajaran konvensional pada kelompok siswa yang memiliki kemandirian belajar tinggi. Secara statistik, hipotesis ini dirumuskan sebagai berikut:

$\mathrm{H}_{0}: \mu_{\mathrm{A} 1 \mathrm{~B} 1} \leq \mu_{\mathrm{A} 2 \mathrm{~B} 1}$

$\mathrm{H}_{1}: \mu_{\mathrm{A} 1 \mathrm{~B} 1}>\mu_{\mathrm{A} 2 \mathrm{~B} 1}$

Keterangan :

$\mu_{\mathrm{A} 1 \mathrm{~B} 1}=$ Rata-rata hasil belajar sejarah kelompok siswa menggunakan media flash player dengan kemandirian belajar tinggi.

$\mu_{\mathrm{A} 2 \mathrm{~B} 1}=$ Rerata hasil belajar sejarah kelompok siswa menggunakan media pembelajaran konvensional dengan kemandirian belajar tinggi.

Hasil uji Tuckey untuk hasil belajar sejarah siswa yang belajar menggunakan media pembelajaran flash player dengan 
kemandirian belajar tinggi $\left(\mathrm{A}_{1} \mathrm{~B}_{1}\right)$ dibandingkan dengan hasil belajar sejarah siswa yang belajar menggunakan media pembelajaran konvensional dengan kemandirian belajar tinggi $\left(\mathrm{A}_{2} \mathrm{~B}_{1}\right)$, diperoleh $Q_{\text {hitung }}=12,59$ dan $Q_{\text {tabel }}=3,95$.

Dengan demikian $Q_{\text {hitung }}>Q_{\text {tabel. }}$ Pengujian terhadap hipotesis ketiga terbukti kebenarannya, dengan ditunjukkan bahwa siswa yang belajar menggunakan media pembelajaran flash player lebih baik secara signifikan daripada siswa yang belajar menggunakan media pembelajaran konvensional pada kelompok siswa dengan kemandirian belajar tinggi.

\section{Uji Hipotesis Keempat}

Hasil belajar sejarah siswa yang belajar menggunakan media pembelajaran flash player lebih rendah dibandingkan dengan media pembelajaran konvensional, pada kelompok siswa yang memiliki kemandirian belajar rendah. Secara statistik, hipotesis ini dirumuskan:

$$
\begin{aligned}
\mathrm{H}_{0}: \mu_{\mathrm{A} 1 \mathrm{~B} 2} & \geq \mu_{\mathrm{A} 2 \mathrm{~B} 2} \\
\mathrm{H}_{1}: \mu_{\mathrm{A} 1 \mathrm{~B} 2} & <\mu_{\mathrm{A} 2 \mathrm{~B} 2} \\
\text { Keterangan : } & \\
\mu_{\mathrm{A} 1 \mathrm{~B} 2}= & \text { Rata-rata hasil belajar sejarah } \\
& \text { kelompok siswa yang belajar } \\
& \text { menggunakan } \\
& \text { pembelajaran flash player dengan } \\
& \text { kemandirian belajar rendah. } \\
= & \text { Rata-rata hasil belajar sejarah } \\
& \text { kelompok siswa menggunakan } \\
& \text { media }
\end{aligned}
$$

konvensional

dengan

kemandirian belajar rendah.

Rata-rata skor hasil belajar sejarah kelompok siswa yang belajar menggunakan media pembelajaran flash player dengan kemandirian belajar rendah adalah 13,67. Sedangkan rata-rata skor hasil belajar sejarah kelompok siswa yang belajar menggunakan media pembelajaran konvensional dengan kemandirian belajar rendah adalah 18,89 .

Hasil uji Tuckey untuk hasil belajar sejarah siswa yang belajar menggunakan media pembelajaran flash player dengan kemandirian belajar rendah $\left(\mathrm{A}_{1} \mathrm{~B}_{2}\right)$ dibandingkan dengan hasil belajar sejarah siswa yang belajar menggunakan media pembelajaran konvensional dengan kemandirian belajar rendah $\left(\mathrm{A}_{2} \mathrm{~B}_{2}\right)$, diperoleh $Q_{\text {hitung }}=6,16$ dan $Q_{\text {tabel }}=3,95$. Dengan demikian $Q_{\text {hitung }}>Q_{\text {tabel. }}$

$$
\text { Pengujian terhadap hipotesis }
$$
keempat terbukti kebenarannya, dengan ditunjukkan bahwa siswa yang belajar menggunakan media pembelajaran konvensional lebih baik secara signifikan daripada siswa yang belajar menggunakan media pembelajaran flash player pada kelompok siswa dengan kemandirian belajar tinggi. Berikut ini disajikan tabel ringkasan hasil uji Tuckey. 
Tabel 4. Rangkuman Hasil Uji Tuckey

\begin{tabular}{|c|c|c|}
\hline \multirow{2}{*}{$\begin{array}{c}\text { Kelompok Yang } \\
\text { Dibandingkan }\end{array}$} & \multirow{2}{*}{$Q_{\text {hitung }}$} & $Q_{\text {tabel }}$ \\
\cline { 3 - 3 } & & $\alpha=0,05$ \\
\hline $\mathrm{A}_{1}$ dan $\mathrm{A}_{2}$ & 4,544 & 3,61 \\
\hline $\mathrm{A}_{1} \mathrm{~B}_{1}$ dan $\mathrm{A}_{2} \mathrm{~B}_{2}$ & 6,59 & 3,95 \\
\hline $\mathrm{A}_{2} \mathrm{~B}_{1}$ dan $\mathrm{A}_{1} \mathrm{~B}_{2}$ & 6,03 & 3,95 \\
\hline $\mathrm{A}_{1} \mathrm{~B}_{1}$ dan $\mathrm{A}_{2} \mathrm{~B}_{1}$ & 12,59 & 3,95 \\
\hline $\mathrm{A}_{1} \mathrm{~B}_{2}$ dan $\mathrm{A}_{2} \mathrm{~B}_{2}$ & 6,16 & 3,95 \\
\hline
\end{tabular}

Berdasarkan analisis data penelitian yang telah dideskripsikan tersebut, maka dilakukan kajian lebih lanjut mengenai media pembelajaran dan kemandirian belajar pada pembelajaran sejarah siswa SMA sebagai berikut:

1. Hipotesis pertama: hasil pengujian hipotesis pertama menolak hipotesis nol yang menyatakan tidak terdapat perbedaan hasil belajar sejarah antara siswa yang belajar menggunakan media pembelajaran flash player dan yang menggunakan media pembelajaran konvensional teruji kebenarannya. Hal ini membuktikan terdapat perbedaan hasil belajar sejarah siswa yang belajar menggunakan media pembelajaran flash player dan siswa yang belajar menggunakan media pembelajaran konvensional. Secara keseluruhan, hasil belajar sejarah siswa yang belajar menggunakan media pembelajaran flash player lebih tinggi dari pada siswa yang belajar menggunakan media pembelajaran konvensional.

2. Hipotesis kedua: hasil pengujian hipotesis kedua menolak hipotesis nol yang menyatakan tidak terdapat pengaruh interaksi antara media pembelajaran dan kemandirian belajar terhadap hasil belajar sejarah siswa SMA. Hal tersebut berarti terdapat pengaruh interaksi antara media pembelajaran dan kemandirian belajar terhadap hasil belajar sejarah siswa SMA.

3. Hipotesis ketiga: hasil pengujian hipotesis ketiga menolak hipotesis nol yang menyatakan bahwa tidak terdapat perbedaan hasil belajar sejarah siswa yang belajar menggunakan media pembelajaran flash player dan yang belajar menggunakan media pembelajaran konvensional pada tingkat kemandirian belajar tinggi. Hal ini berarti hasil belajar sejarah siswa yang belajar menggunakan media pembelajaran flash player lebih tinggi bila dibandingkan siswa yang belajar menggunakan media pembelajaran konvensional pada tingkat kemandirian belajar tinggi.

4. Hipotesis keempat: hasil pengujian hipotesis keempat, menolak hipotesis nol yang menyatakan tidak terdapat perbedaan hasil belajar siswa menggunakan media pembelajaran flash player dan yang belajar menggunakan media pembelajaran konvensional tingkat kemandirian belajar rendah. Rerata skor hasil belajar siswa yang belajar menggunakan media pembelajaran flash player lebih rendah dibandingkan siswa yang belajar menggunakan media pembelajaran 
konvensional. Bagi siswa dengan kemandirian belajar rendah, penggunaan media pembelajaran konvensional memungkinkan mendapatkan pembelajaran sesuai dengan tingkat kemampuannya. Dengan demikian, siswa dengan tingkat kemandirian belajar rendah lebih cocok belajar dengan media pembelajaran konvensional dibanding belajar menggunakan media pembelajaran flash player.

\section{Penutup}

\section{A. Kesimpulan}

Adapun kesimpulan dari penelitian ini adalah Pertama, Secara keseluruhan hasil belajar sejarah kelompok siswa yang belajar menggunakan media pembelajaran flash player lebih tinggi daripada kelompok siswa yang belajar menggunakan media pembelajaran konvensional, Kedua, Terdapat pengaruh interaksi antara media pembelajaran dan kemandirian belajar terhadap hasil belajar sejarah siswa SMA,

Ketiga, untuk siswa dengan kemandirian belajar tinggi, kelompok siswa yang belajar menggunakan media pembelajaran flash player lebih tinggi dibanding kelompok siswa yang belajar menggunakan media pembelajaran konvensional, Keempat, untuk siswa dengan kemandirian belajar rendah, kelompok siswa yang belajar menggunakan media pembelajaran flash player lebih rendah dibanding kelompok siswa yang belajar menggunakan media pembelajaran konvensional

\section{B. Saran}

Pertama, dalam pembelajaran sejarah SMA Kelas XI-IPA, guru dapat menggunakan media pembelajaran flash player dan media pembelajaran konvensional, Kedua, untuk penggunaan media pembelajaran flash player dan media pembelajaran konvensional, guru hendaknya memperhatikan tingkat kemandirian belajar siswa sebagai upaya untuk meningkatkan hasil belajar siswa,

Ketiga, berdasarkan hasil penelitian, penggunaan media pembelajaran flash player dapat meningkatkan hasil belajar siswa yang memiliki kemandirian belajar tinggi dan media pembelajaran konvensional dapat meningkatkan hasil belajar siswa yang memiliki kemandirian belajar rendah, sebaiknya guru lebih selektif dalam memilih media pembelajaran bagi siswa dengan tingkat kemandirian belajar yang beragam.

\section{Daftar Pustaka}

Andi. (2004). Panduan Aplikasi Menguasai Macromedia Flash MX 2004. Yogyakarta: Andi Offset.

Arikunto, Suharsimi. (2008). Dasar-dasar Evaluasi Pendidikan. Jakarta: Bumi Aksara.

Arsyad. (2012). Media Pembelajaran. Jakarta: Raja Grafindo.

B Uno, Hamzah. (2012). Orientasi Baru Dalam Psikologi Pembelajaran. Jakarta: Bumi Aksara. 
Djamarah, B.S dan A. Zain. (2006). Strategi Belajar Mengajar. Jakarta: Rineka Cipta.

Hamalik, Oemar. (2012). Proses pembelajaran. Jakarta: Bumi Aksara.

Hargis, Jace. (2000). The Self-Regulated Learner Advantage: Learning Science on the Internet. Electronic Journal of Science Education. 4. Diakses dari http://wolfweb.unr.edu/homepage/c rowther/ejse/hargis.html.

Kamii, Constance. (2000). Pendidikan Nilai Memasuki Tahun 2000 (Kemandirian Sebagai Tujuan Pendidikan). Jakarta: Gramedia Widiasarana Indonesia.

Miarso, Yusufhadi. (2004). Menyemai Benih Teknologi Pendidikan. Jakarta: Prenada Media.

Munir. (2008). Kurikulum Berbasis Teknologi Informasi dan Komunikasi. Bandung: Alfabeta.

Rusman. (2009). Manajemen Kurikulum. Bandung: Rajawali Press.

S, Sumahamijaya, Yansen D dan Dana D.A. (2003). Pendidikan karakter Mandiri dan Kewirausahaan. Bandung: Penerbit Angkasa.

Sadiman, Arief S. (2012). Media Pendidikan. Jakarta: Raja Grafindo Persada.

Smaldino, S.E. (2005). Instructional Technology And Media For Learning $8^{\text {th }}$ Edition. New Jersey: Pearson, Merrill Prentice Hall.

Susilana dan Riyana. (2008). Media Pembelajaran. Bandung: FIP UPI.

Thobroni, Muhamad, Arif Mustofa. (2011). Belajar \& Pembelajaran: Pengembangan Wacana Dan Praktik Pembelajaran Dalam Pembangunan Nasional. Yogyakarta: Ar-Ruzz Media.

Winkel, W.S. (2009). Psikologi Pengajaran. Yogyakarta: Media Abadi. 